\title{
Sparassidae - the valid scientific name for the huntsman spiders (Arachnida: Araneae)
}

\section{Peter JÄGER}

Abstract: Sparassidae - the valid scientific name for the huntsman spiders (Arachnida: Araneae). The family name Sparassidae is recognized as available and valid according to the rules of the International Code for Zoological Nomenclature. Synonymies, diagnoses and descriptions are given for the family, subfamily, type genus and type species. The type species of Sparassus is assigned. Sparassus is synonymised with Micrommata.

Key words: Sparassidae, Sparassus, Micrommata, family name, nomenclature

\section{INTRODUCTION}

In recent times three different family names have been used for the huntsman or giant crab spiders in collections (e.g. Tervuren, London) and in scientific papers: Sparassidae Bertkau 1872 (e.g. LEVY 1989), Heteropodidae Thorell 1873 (e.g. HIRST 1995), Eusparassidae Järvi 1912 (e.g. BARRION \& LITSINGER 1995). In the catalogues of PLATNICK $(1989,1993,1998)$ and consequently in several publications Heteropodidae is used (as introduced by PLATNICK \& LEVI 1973), although Sparassidae was introduced already by BERTKAU (1872). Eusparassidae Järvi 1912 was used in the catalogues of ROEWER (1954) and BRIGNOLI (1983), Sparassidae Simon 1874 in the catalogue of BONNET (1958). As all three available family names are still in usage, this problem was investigated and a solution is proposed here.

NOMENCLATURAL HISTORY

\section{Family Sparassidae Bertkau 1872}

BERTKAU (1872) included in his "Sparassides" the name-giving genus Sparassus and in addition Thanatus (now Philodromidae). The described 
family name is available and valid in the framework of the rules of ICZN (1962: 5-10, 12-14; KRAUS 1973: 221).

\{It was possible for the author to have a look at an unpublished draft of the new edition of the ICZN. The passages cited here from the earlier edition are in conformity with those of the new edition.\}

Heteropodidae was described one year later by THORELL (1873) with seven genera included. One genus, Selenops, belongs now to the Selenopidae, another genus, Hemicloea, to the Gnaphosidae. The other five genera are Heteropoda, Micrommata, Sparassus, Delena and Voconia (preocc., now Holconia: HIRST 1991). The listing of Micrommata in addition to Sparassus may be the origin of the nomenclatorical confusion. SIMON (1874) used the name Sparassidae and listed also Micrommata besides Sparassus and included in his Sparassus species of the more recent Eusparassus, Olios and South American species, which do not belong to these two genera. JÄRVI (1912) introduced Eusparasseae as a new tribe name and listed the tribe Micrommateae in the sense of the recent subfamily Sparassinae.

KASTON $(1938,1974)$ discussed the problem in general with respect to several different family names. PLATNICK \& LEVI (1973) explained that Sparassidae Bertkau 1872 had an "unrecognizable" type genus: Sparassus Walckenaer 1805. Therefore they proposed to use Heteropodidae Thorell 1873 instead, until a revision of this family had been done. CROESER (1986) published a "proposed solution for submission to the International Commission on Zoological Nomenclature", but there is no such case pending, nor has anything ever been published since then by the Commission (Kropf, pers. comm.).

In the preamble of the ICZN (1962) it is pointed out that priority is the basic principle of the zoological nomenclature. One exception is the case when a name is endangered. To save one name, another might/must be suppressed. The "suppression of unused later synonyms" is only possible, if this name has not been used for the last 50 years (KRAUS 1973:224). But the name "Sparassidae" has been used at least 11 times in this period by at least eleven different authors. "Heteropodidae" has been used almost exclusively for only the last 25 years, whereas "Sparassidae" has been in steady use for the past 127 years. Following ICZN (1962: 21, Art 40, [1]) the earlier family name has to be retained, although the type genus (Sparassus) is a junior synonym of another genus (Micrommata). 
Note: The family names "Attidae" and "Drassidae" have been changed correctly to "Salticidae" and to "Gnaphosidae", respectively, as their type genera had been synonymised before 1961 (ICZN 1962: Art. 40, 21 [a]), whereas Sparassus has still not been synonymised validly (see also paragraph "Genus Sparassus", below).

\section{Subfamily Sparassinae Bertkau 1872}

If a family name is described, a subfamily name is available using the author's name and the year of family's description, if it is based on the same type genus (ICZN 1962: 20, Art. 36). Thus Sparassinae Bertkau 1872 is valid. The subfamily Sparassinae sensu Simon (described sub Sparasseae 1897 ) is not identical with Sparassinae Bertkau 1872.

\section{Genus Sparassus Walckenaer 1805}

Although Sparassus Walckenaer 1805 was not validly synonymised in former times, this genus has not turned up in the catalogues of BRIGNOLI (1983) and PLATNICK $(1989,1993,1998)$.

WALCKENAER (1805) included five species in his genus description of Sparassus: S. samaragdulus (Fabricius 1793), S. roseus (Clerck 1757), S. ornatus (Walckenaer 1802), S. argelasius (nomen nudum) and S. pallens (Fabricius 1794). The first three species he listed in a subgroup "Les Mycromates", the two latter species in "Les Opticiennes". Sparassus argelasius is not available as a type species, because a species description is not given in the genus description in 1805 , so it is a nomen nudum. WALCKENAER (1806) published the description one year later.

Sparassus pallens Fabricius 1794 is described from a juvenile spider from the Antilles (FABRICIUS 1794:461). The species cannotbe recognized by the original description, which was also repeated to the letter four years later (FABRICIUS 1798). ROEWER (1954: 713) synonymised Sparassus pallens with Heteropoda venatoria (Linnaeus 1758) as LATREILLE (1806) listed it as a synonym of this circumtropical species sub Thomisus venatoria. $\mathrm{KOCH}$ (1838) figured one male of Ocypete pallens (Fabricius 1794), which might be Heteropoda venatoria. PLATNICK \& LEVI (1973) considered either Sparassus pallens to be an Olios-species and Sparassus as a possible senior synonym of Olios or Sparassus to be a junior synonym of Micrommata. 
Denominations of type species for Sparassus were presented by THORELL (1870: 176) and BONNET (1958: 4098). THORELL (1870) recognized that several species of the genus Sparassus (Les Mycromates) actually belonged to Micrommata and took Sparassus argelasius as the type species for Sparassus (Les Opticiennes). Following ICZN (1962) this is an invalid denomination, as this species was a nomen nudum, when Walckenaer described the genus Sparassus 1805. Thus it is not available as type species. BONNET (1958) named Sparassus dufouri (=Eusparassus dufouri) as type species, which was not included in the genus by WALCKENAER (1805) as an available species in the sense of ICZN (1962). LEVY (1989) followed the designation of BONNET (1958).

[The situation is more complicated as it seems here: Sparassus argelasius o turned into Eusparassus dufouri, $S$. argelasisus ${ }^{\lambda}$ into Olios argelasius. BONNET tried to save both genus names: Olios and Sparassus beside Micrommata (PLATNICK \& LEVI, 1973), and synonymised Eusparassus with Sparassus.\}

Consequently, there are three species (Sparassus samaragdulus (Fabricius 1793), S. roseus (Clerck 1757), S. ornatus (Walckenaer 1802)), which are obviously synonyms of Micrommata virescens Clerck 1757. BERTKAU (1872) wrote in the description of his "Sparassides" "Micrommata?" in brackets behind Sparassus, as he did not know the genus Micrommata at this time. Six years later he stated that he had described the family after Micrommata virescens and that he did not know the genus Sparassus (BERTKAU, 1878: "...Ich hatte den Familiennamen nach Sparassus gebildet, obwohl die Art ( virescens) jetzt zu Micrommatagerechnet wird und ich jetzt umgekehrt sagen müsste, dass ich die Gattung Sparassus nicht kenne..."). This supports the synonymisation of Sparassus with Micrommata and thus that Micrommata virescens would be type species of the family, because BERTKAU described the family in fact from this species, although he was not sure whether Sparassus and Micrommata were two different genera or not. The synonymy of Sparassus with Micrommata was recognized by former authors, though there was no type species assigned.

All these facts made me assign Aranea smaragdula Fabricius 1793 as type species of the genus. This species is readily recognizable by the original description of FABRICIUS (1793) and following descriptions. As Micrommata smaragdina Latreille 1806 is a junior synonym of Aranea smaragdula Fabricius 1793 (see next paragraph), Sparassus Walckenaer 1805 becomes definitively a junior synonym of Micrommata Latreille 1804. 
LATREILLE (1804) states that his "Micromata" comprises the spiders that Walckenaer calls "les Grottiformes", but included no nominal species. Two years later he described the species Micrommata smaragdina Latreille 1806. In the list of synonymies he listed besides the names Araignee touteverte Degeer, Araneus smaragdula Fabricius, Sparasse emeraudine Walckenaer and Araignee emeraudine Latreille and he refers to CLERCK (1757) without giving a species name but with the addition "Aran. Suec., pag. 136, pl. 6, tab. 4". Though the page-number is wrong (lapsus pro"138"), the drawing obviously points to Araneus virescens Clerck 1757. Following ICZN (1962: 69, [a] [ii] [2]) therefore Micrommata virescens (Clerck 1757) is ipso facto type species of Micrommata Latreille 1804 by subsequent (secondary) monotypy.

\section{Species Micrommata virescens (Clerck 1757)}

Micrommata virescens (Clerck 1757) is probably the most often figured sparassid spider because of its characteristic coloration and its occurence in Central Europe. Because of this, it is well recognizable throughout all descriptions as well in pictures as in only written descriptions. It was described under several names and often under different names for both sexes and additionally the juvenile form separately ( $M$. ornata).

The valid name is stated by the first revising author (ICZN 1962: 13) who is in this case $\mathrm{KOCH}(1845: 87,88)$ as already accepted by THORELL (1856: 75). The name $M$. rosea re-introduced by BONNET (1957: 2889) should therefore be abandoned.

Because Sparassus Walckenaer 1805 is synonymous with Micrommata Latreille 1804 and the latter is the type genus of the Sparassidae, Micrommata virescens (Clerck 1757) is ipso facto type species of the Sparassidae.

Because of the facts listed above I consider that the earliest available family name, Sparassidae Bertkau 1872, to be the valid name for the huntsman spiders. 


\section{TAXONOMY}

\section{Family Sparassidae Bertkau 1872}

(Type genus: Micrommata Latreille 1804)

Sparassidae Bertkau 1872: 232 (sub Sparassides)

Heteropodidae Thorell 1873: 606 (sub Heteropodoidae; junior synonym)

Sparassidae Simon 1874: 243 (objective synonym)

Eusparassidae Järvi 1912: 108 (sub Eusparasseae; junior synonym)

Diagnosis: Spiders with a soft dorsal trilobate membrane at the distal end of metatarsi of walking legs.

Description: Small ( $3 \mathrm{~mm})$ to large $(38 \mathrm{~mm})$ labidognath, two-clawed spiders; laterigrade legs with scopulae at tarsi and metatarsi (partly); eight eyes in two rows; chelicerae with two or three teeth at promargin and two to seven teeth at retromargin; with or without denticles at cheliceral furrow; chiefly nocturnal.

Distribution: Ca. between $40^{\circ} \mathrm{N}$ and $40^{\circ} \mathrm{S}$, except for Micrommata virescens (palaearctic).

\section{Subfamily Sparassinae Bertkau 1872}

(Type genus: Micrommata Latreille 1804)

Palystinae Simon 1897: 31 (part., sub Palysteae)

Micrommatinae Järvi 1912: 108 (sub Micrommateae, junior synonym)

Diagnosis: no diagnosis can be given until a revision of this subfamily is carried out and the subfamily is clearly delimited.

Distribution: see Sparassidae, but without Australia

\section{Genus Micrommata Latreille 1804}

(Type species: Araneus virescens Clerck 1757; LATREILLE (1804): 135 and LATREILLE (1806): 115, 116; by subsequent monotypy)

Note: gender is feminine (PLATNICK 1993: 79, 692; ICZN 1962: 30, [a] [i] [3])

Micrommata Latreille 1804: 135 (sub Micromata, lapsus)

Sparassus Walckenaer 1805 (Type species: Aranea smaragdula Fabricius 1793; here assigned) NEW SYNONYMY 
Diagnosis: Greenish coloured sparassids with recurved anterior and procurved posterior eye row with nearly equal eye sizes.

Description: Medium-sized $(6.5-15 \mathrm{~mm})$ spiders; median eyes closer to lateral eyes than to each other; anterior median eyes slightly smaller than all other eyes; margins of eyes covered by white hairs; chelicerae with two promarginal and five (two larger distal and three smaller basal) retromarginal teeth \{3-4 retromarginal teeth after LEVY (1989)\}; tarsal claws with 17-22 comb-like teeth; in females with distinctly stronger distal tooth; female palpal claw with ca. 9 teeth; males with rigid screw-like embolus; tibial apophysis simple; females with structured epigyneal plate with two anterior lobes; genital openings situated anteriorly; functional final parts of internal duct system running outwards to posteriorly situated fertilisation ducts; diurnal; in low vegetation (grass, herblayer) (see also LEVY 1989).

Distribution: Palaearctic, including North Africa

All three known European and Mediterranean species - Micrommata virescens (Clerck 1757), Micrommata ligurina (C. L. Koch 1845) and Micrommata formosa Pavesi 1878 - were examined by the author. They are closely related to each other and belong clearly to one genus. On the other hand belongs Micrommata to the Sparassidae, as it has the trilobate membrane like all other sparassid representatives (JÄGER 1998).

\section{Micrommata virescens (Clerck 1757)}

(Type material presumably lost [HOLM, 1978])

Araneus roseus CLERCK 1757: 137

Araneus virescens CLERCK 1757: 138

Aranea smaragdula FABRICIUS 1793: 412

Aranea ornata WALCKENAER 1802: 226

Sparassus smaragdulus: WALCKENAER 1805: 39

Sparassus roseus: WALCKENAER 1805: 40

Sparassus ornatus: WALCKENAER 1805: 40

Aranea smaragdina LATREILLE 1806: 115

Sparassus virescens: $\mathrm{KOCH}$ 1845: 87

Sparassus roseus: KOCH 1845: 88 (= Sparassus virescens, syn.)

Araneus virescens: THORELL 1856: 75

Sparassus virescens var. ornata: NOWICKI 1874: 8 (new rank)

Micrommata ornata: KARSCH 1885: 533 (= M. virescens, juv., syn.)

For further synonyms see catalogues of BONNET (1957) and ROEWER (1954) 
Diagnosis: Male - Straight tibial apophysis reaches basal part of embolus; tip of embolus raised distad, without hook (see LEVY 1989 for comparison with the other two species of the genus)

Female - epigyne with posterior margin pointed posteriad; anterior turning of internal ducts well visible in dorsal view

Description: see genus description

Distribution: Palaearctic

\section{ZUSAMMENFASSUNG}

Aufgrund der unbefriedigenden Situation, daß dreiwissenschaftliche Namen für die Familie der Riesenkrabbenspinnen in Gebrauch sind (Sparassidae Bertkau 1872, Heteropodidae Thorell 1873, Eusparassidae Järvi 1912), wurden die nomenklatorischen und taxonomischen Hintergründe untersucht, wobei folgende Ergebnisse erbracht wurden:

Der Familienname Sparassidae Bertkau 1872 ist nach ICZN (1962) verfügbarund gültig. Erwurde seit seiner Einführung 127 Jahre durchgehend benutzt, wohingegen Heteropodidae Thorell 1873 durch PLATNICK \& LEVI (1973) eingeführt und fast ausschließlich in den letzten 25 Jahren gebraucht wurde.

Sparassinae Bertkau 1872 ist gültiger Name für die Nominat-Unterfamilie.

Die Gattung Sparassus Walckenaer 1805 hatte bis dato noch keine gültig festgelegte Typusart. Nach eingehendem Studium der Originalliteratur wird Aranea smaragdula Fabricius 1793 als Typusart festgelegt. Da sich diese Art in der Synonymie von Micrommata virescens (Clerck 1757) befindet und diese Typusart von Micrommata Latreille 1804 ist, ist Sparassus jüngeres Synonym von Micrommata (NEUE SYNONYMIE).

Damit ist Micrommata virescens (Clerck 1757) Typusart der Familie Sparassidae Bertkau 1872.

ACKNOWLEDGMENTS: I want to thank Dr M. Grasshoff (Frankfurt) for lengthy and helpful discussions and his hospitality in the Senckenberg Museum. I also thank Prof. Dr O. Kraus (Hamburg), Dr M. Kreuels (Münster), Dr C. Kropf (Bern), Prof. Dr H. Levi (Cambridge, Mass.), Dr G. Levy (Jerusalem), Prof. Dr J. Martens (Mainz), Dr J. Murphy (Hampton), Dr H. Ono (Tokyo), Dr N. I. Platnick (New York), Dr K. Thaler (Innsbruck) and Dr P. Tubbs (London) for discussions, corrections and information. 


\section{LITERATURE}

BARRION, A. T. \& J. A. LITSINGER (1995): Riceland spiders of South and Southeast Asia. CAB International, Wallingford, England, i-xv $+700 \mathrm{pp}$.

BERTKAU, P. (1872): Ueber die Respirationsorgane der Araneen. Inaugural-Dissertation zur Erlangung der Doctorwürde der philosophischen Fakultät der Rheinischen FriedrichWilhelms-Universität zu Bonn. - Arch. Naturg. 38 (2): 208-233

BERTKAU, P. (1878): Versuch einer natürlichen Anordnung der Spinnen nebst Bemerkungen zu einzelnen Gattungen. - Arch. Naturg. 44 (1): 351-410

BONNET, P. (1957): Bibliographia araneorum. Vol. 2(3). - Douladoure, Toulouse. S. 19273026

BONNET, P. (1958): Bibliographia araneorum. Vol. 2(4). - Douladoure, Toulouse. S. 3027 4230

BRIGNOLI, P. M. (1983): A catalogue of the Araneae described between 1940 and 1981. - University Press, Manchester. 755 pp.

CLERCK, C. (1757): Aranei suecici, descriptionibus et figuris aeneis illustrati, ad genera redacti, speciebus ultra Ix determinati, auspiciis regiae societatis scientiarum Upsaliensis. - Literis Laur. Sal VII. Stockholmiae. 154 pp., 6 pl.

CROESER, P. (1986): Sparassidae, Heteropodidae or Eusparassidae?(Arachnida: Araneida). A proposed solution for submission to the International Commisssion on Zoological Nomenclature. - Actas X Congr. Int. Aracnol. Jaca/Espana, 1986. I: 415

FABRICIUS, J. C. (1793): Entomologia systematica emendata et aucta. Secundum classes, ordines, genera, species adjectis synonymis, locis, observationibus, descriptionibus. Tom. II. Araneae. - Proft, Hafniae. 407-428

FABRICIUS, J. C. (1794): Entomologia systematica emendata et aucta. Secundum classes, ordines, genera, species adjectis synonymis, locis, observationibus, descriptionibus. Tom. IV. Araneae. - Proft, Fil et Soc., Hafniae. 460-462

FABRICIUS, J. C. (1798): Supplementum entomologiae systematicae. - Proft et Storch, Hafniae. 1-572

HIRST, D. B. (1991): Revision of Australian species of the genus Holconia THORELL (Heteropodidae: Araneae). - Rec. S. Aust. Mus. 24 (2): 91-109

HIRST, D. B. (1995): Further studies on the Australian Heteropodidae (Araneae): a new species of Pediana SIMON, and description of the male Zachria flavicoma L. $\mathrm{KOCH}$.

- Rec. West. Austral. Mus. (Suppl.) 52: 145-149

HOLM, A. (1978): Om Carl Clercks spindelsamling. - Fauna och Flora 73: 201-205

ICZN (1962): Internationale Regeln für die Zoologische Nomenklatur beschlossen vom XV. Internationalen Kongress für Zoologie. Frankfurt. 90 pp.

JÄGER, P. (1998): First results of a taxonomic revision of the SE Asian Sparassidae (Araneae). - In: P. A. Selden, (ed.): Proceedings of the 17th European Colloquium of Arachnology, Edinburgh, 1997. Burnham Beeches, Bucks: 53-59

JÄRVI, T.H. (1912/1914): Das Vaginalsystem der Sparassiden. - Ann.Acad.Sci.Fenn. A4: 1-248, Taf. 1-11; Helsinki [1912: 1-131 \& 11pl, 1914: 132-248]

KARSCH, F. (1885): Zur Frage Saison-Dimorphismus bei Spinnen? - Zool. Anz. 8: 532-533. KASTON, B. J. (1938): Family names in the order Araneae. - American Midl. Natural. 19 (3): 638-646

KASTON, B. J. (1974): Remarks on the names of families and higher taxa in spiders. - J. Arachnol. 2: 47-51 
$\mathrm{KOCH}, \mathrm{C} . \mathrm{L}$. (1838): Die Arachniden. Getreu nach der Natur abgebildet und beschrieben. (Fortsetzung des Hahn'schen Werkes.). Vierter Band. - Zeh'sche Buchhandlung, Nürnberg. 1-144

KOCH, C. L. (1845): Die Arachniden. Getreu nach der Natur abgebildet und beschrieben. Zwölfter Band. - Zeh'sche Buchhandlung, Nürnberg. 1-166

KRAUS, O. (1973): Internationale Regeln für die Zoologische Nomenklatur: Bericht über Änderungen, gültig ab 1. Januar 1973. - Senckenbergiana biol. 54 (1/3): 219-225

LATREILLE, P. A. (1804): Tableau methodique des Insectes. - Nouv. Diction. hist. nat. 24 (Deterville, Paris): 129-200

LATREILLE, P.A. (1806): Genera Crustaceorum et Insectorum secundum ordinem naturalem in familis dicsposita, iconibus exemplique plurimis explicata. - Argentorati Koenig, Paris, 82-127, Tab. VI.

LEVY, G. (1989): The family of huntsman spiders in Israel with annotations on spiders of the Middle East (Araneae: Sparassidae). - J. Zool. London 217 (1): 127-176

NOWICKI, M. (1874): Dodatek do fauny pajeczykow Galicyi. - Spraw. kom. fizyogr. Krakow 8: 1-11

PLATNICK, N. I. (1989): Advances in Spider Taxonomy 1981-1987. A supplement to Brignoli's 'A catalogue of the Araneae described between 1940 and 1981'. - New York, $673 \mathrm{pp}$.

PLATNICK, N. I. (1993): Advances in Spider Taxonomy 1988-1991. With Synonymies and Transfers 1940-1980. - New York, 846 pp.

PLATNICK, N. I. (1998): Advances in Spider Taxonomy 1992-1995. With Redescriptions 1940-1980. New York, 976 pp.

PLATNICK, N. I. \& H. W. LEVI (1973): On family name of spiders. - Bull. Br. arachnol. Soc. 2 (8): 166-167

ROEWER, C. F. (1954): Katalog der Araneae von 1758 bis 1940. Bd. 2 a. - Bruxelles, 1-923.

SIMON, E. (1874): Etudes arachnologique. $3^{3}$ mémoire (1). V. Revision des espèces européennes de la famille des Sparassidae. - Ann. Soc. ent. France (5) 4: 243-279, pl. V.

THORELL, T. (1856): Recenso critica Aranearum Suecicarium quas descripserunt Clerckius, Linnaeus, De Geerus. - N. Act. reg. Soc. sci. Upsal. (3) 2 (1): 61-176

THORELL, T. (1870): On European spiders. PartI. Review of the European genera of spiders, preceded by some observations on zoological nomenclature. - N. Act. reg. Soc. sci. Upsal. (3) 7 (2): 109-242

THORELL, T. (1873): Remarks on synonyms of European spiders. Part IV. - N. Act. reg. Soc. sci. Upsal. (3) 7: 375-645

WALCKENAER, C. A. (1805): Tableau des Aranéides ou caractères des tribus, genres, familles et races que renferme le genre Aranea de Linné, avec la designation des especes comprises dans chacune de ces divisions. - Deterville, Paris. 88 pp.

WALCKENAER, C. A. (1806): Histoire naturelle des Araneides. - Koenig, Paris-Strasbourg. $184 \mathrm{pp}$.

Peter JÄGER, Insitut für Zoologie, Johannes Gutenberg-Universität, Saarstraße 21, 55099 Mainz 